\title{
Farm worker injuries on Western Cape fruit farms: The role of the Lay Health Worker
}

\author{
S Marais, D. Litt et Phil (Sociology) \\ Medical Research Council \\ A Kritzinger, D.Phil \\ Professor of Sociology, University of Stellenbosch
}

Key words:

Injuries, agricultural sector, lay health worker, alcohol-related injuries.

\section{Correspondence address:}

Dr Sandra Marais

Medical Research Council

PO Box 19070

Tygerberg

7505

Tel: (021) 9380407

Fax: (021) 9380381

E-mail address: Sandra.marais@mrc.ac.za

\section{Abstract: Curationis 28(4): 86-92}

Aim and method: An exploratory and descriptive study to obtain basic data on the extent, nature, sources and severity of injuries sustained on fruit farms was conducted. The possibility of utilizing lay health workers (LHWs) on farms to document routine information on injuries was also investigated. Descriptive information of all injuries occurring on selected farms, both occupational and other, needing some form of treatment, were documented over a one-year period from June 1999 to May 2000. A purposive non-probability sampling method was used. Forty-eight fruit farms with a history of trained LHWs were purposefully selected. Injuries were documented using a one-page questionnaire.

Results: A total of 500 injuries were recorded, giving an average of 10.4 injuries per farm per year. Half of these injuries were work-related. Workers aged 20-39 were most at risk. Injuries sustained were related to routine activities of fruit farming, occurred mostly in the orchards and involved cuts, bruises and abrasions to the hands, including the fingers, and the eyes.

Most of the non-work related injuries occurred in and around the home. A third of these injuries were sustained by persons $<20$. A large percentage of the non-work related injuries were violence- and alcohol related. Most of the injuries required basic primary health care that could be managed by the LHW. Injury severity caused people to take time off for one third of the cases.

Conclusion: A relatively high occupational injury rate in comparison to high-income countries. Occupational Health and Safety legislation needs to be institutionalized and adhered to. Alcohol and violence on farms is a serious public health problem. LHWs could potentially play an important role in documenting injury data.

\section{Opsomming}

Doel en metode: ' $n$ Eksplorerende en beskrywende studie om die omvang, aard, bronne en ernstigheidsgraad van beserings op vrugteplase te bepaal, is onderneem. Die moontlikheid om leke-gesondheidswerkers (LGWs) op plase te gebruik om die inligting te dokumenteer is ook ondersoek. Beskrywende inligting van alle beserings op geselekteerde plase, beide beroeps- en ander beserings, wat een of ander vorm van behandeling benodig, is gedokumenteer oor ' $n$ tydperk van een jaar, vanaf Junie 1999 tot Mei 2000. 'n Doelgerigte nie-ewekansige steekproef metode is gebruik. Agt-enveertig vrugteplase met ' $n$ geskiedenis van opgeleide LGWs is gekies vir insluiting in die steekproef. Beserings is gedokumenteer op ' $n$ enkelbladsy vraelys.

Bevindinge: ' $n$ Totaal van 500 beserings is gedokumenteer wat ' $n$ gemiddeld van 10.4 beserings per plaas per jaar aandui. Die helfte van die beserings was werkverwant. Werkers tussen die ouderdomme van 20-39 het die grootste risiko vir beserings geloop. Beserings opgedoen was verwant aan roetine-aktiwiteite op vrugteplase, het meeste 
plaasgevind in die boorde en het snywonde, kneusings en skaafwonde aan die hande, vingers en oë ingesluit. Meeste van die nie-werkverwante beserings gebeur in en rondom die huis. 'n Derde van die nie-werkverwante beserings het kinders onder die ouderdom van 20 jaar ingesluit. ' $n$ Groot persentasie van die nie-werkverwante beserings was te wyte aan geweld en was ook alkohol-verwant. Die meerderheid van die beserings was nie van 'n ernstige aard nie en kon hanteer word deur die LGW op die plaas. ' $n$ Derde van die beserings was ernstig genoeg om mense van hul werk en take weg te hou.

Gevolgtrekking: 'n Relatief hoë beseringskoers in vergelyking met ontwikkelde lande wêreldwyd is gevind. Beroepsgesondheid en Veiligheidswetgewing moet nog geinstitusionaliseer word en beter toegepas word. Alkoholmisbruik en geweld op plase bly steeds ' $n$ ernstige openbare gesondheidsprobleem. LGWs kan potensiëel ' $\mathrm{n}$ baie belangrike rol speel in dokumentering van data.

\section{Background}

Internationally, farming is considered to be one of the most hazardous occupations, with farm workers facing a wider range of hazards than most other workers (MMWR, 2001: 317; Hayden, Gerberich \& Maldonado, 1995: 571; Rogers, Shackford, Osler, Vane, Davis, 1999: 802; Fragar, 1996: 200; Dimich-Ward, Guernsey, Pickett, Rennie, Hartling, Brison, 2004: 52, Demers \& Rosenstock, 1991: 1656). In parts of the USA, deaths due to agricultural injuries are nearly 5 times greater than the rate for all occupations combined, while morbidity accounts for a rate of more than 2.5 times greater than for all occupations (Hayden, Gerberich \& Maldonado, 1995: 571). Risk for occupational injury varies from between 16 and 60 per 100 farms per year in Australia (Fragar, 1996: 200) and between 5 to 10 per 100 farm workers per annum globally (Dimich-Ward et al, 2004: 52). Moreover, preventive measures in agriculture are seen to lag behind those in most other occupations (Fragar, 1996: 200; Baxter, 1992: 6; Hartling, Picket \& Brison, 1998: 108; Myers, 1990: 163; Kelly, 1994: 112). Rural trauma was justifiably labeled the 'neglected disease of the nineties' (Rogers, et al, 1997: 802), and it still is. The burden of agricultural injuries not only reflects deficiencies in the application of health and safety regulations for workers on farms, but is also costly as far as farm production and treatment of these injuries are concerned. In South Africa, relatively little data is available on farm worker injuries. Although it is recognized that agriculture is one of the major sectors contributing to a high fatality rate (agriculture contributed $16 \%$ of fatal occupational injuries in 1994, second only to the transport sector according to Jeebhay and Jacobs, 1999: 261), there is no systematic collection of agricultural injury data in this country. Collection of data on farm worker injuries is a worldwide problem (Gunderson, Gerberich, Gibson, Adlis, Carr, Erdman, 1990: 170). Distances between farms hamper the collection of data on an ongoing basis. Information is usually gathered from a variety of sources, for instance, compensation claim forms, hospital injury data and telephonic surveys, all of which have specific limitations. Furthermore, the comparison of data also poses problems because of the variable risk of injury associated with production of different commodities (Fragar, 1996: 203), and the variation in data sources and reliability of data. These variations and the absence of ongoing surveillance systems inevitably result in the underestimation of farm related injuries and therefore make it extremely difficult to develop appropriate strategies for prevention. Unique to agriculture as a primary industry is that the farm acts as place of residence as well as place of employment. Children, the elderly, and other nonworkers living on the farm are also exposed to risks for injuries as are workers (Hayden et al, 1995: 572; DimichWard et al, 2004: 52). Surveillance of injuries on farms and accompanying preventative actions should therefore include all injuries and not only those sustained during working hours.

The primary aim of this exploratory and descriptive study was to obtain data on the extent, nature and sources of injuries sustained on a selection of fruit farms. Secondary to this aim was to investigate the possibility of utilizing lay health workers (LHWs) on farms to document information on injuries and in so doing to create a simple database for injury surveillance.

\section{Setting of the study History of lay health worker training on farms}

Since the eighties, farm workers on fruit and wine farms in the Western Cape have been targeted by different community development groups and nongovernmental organizations (NGO's) for skills enrichment and development programmes. In one of these programmes LHWs (usually a female worker chosen by other workers on the farm) were trained in the principles of first aid and general knowledge of a range of basic health issues. They could attend to minor ailments such as headaches, sprains, and minor injuries and alert an appropriate person in the case of a serious condition or injury. LHWs on farms therefore play a vital role in providing primary and immediate care to farm workers and add significantly to cost savings for the farm manager. Because of distances from towns and the relative isolation on farms, farm workers do not have regular access to formal health services. Mobile clinic services visit farms on a regular but intermittent basis, hence the importance of trained LHWs. Most of these health workers were also trained to keep records on a routine basis.

\section{Background to labour regimes on farms}

Commercial farming is by far the most important economic activity in the rural areas of the Western Cape. The deciduous fruit industry makes the largest single contribution to the value of agricultural output in the area. The industry is essentially export oriented and labour intensive. Since the mid-nineties the South African fruit centre has experienced significant changes following its reintegration into the global economy and the extension of legislative protection to farm workers. These changes have involved modifications in the global value chain linking this sector to the United Kingdom (UK) and European supermarkets, deregulation of fruit export markets and the extension of labour legislation to farm workers (Barrientos \& Kritzinger, 2004: 84-86). To maintain a competitive advantage within global markets and comply with stipulations set by labour legislation (including stipulations on health and safety of workers) and UK supermarkets, producers have pursued different employment strategies.

Although farmers' employment strategies have varied, an important trend has been to downsize their permanent on-farm workers and increase the use of different categories of flexible off-farm workers, for 
example contract-, casual-, seasonal- and temporary workers (Barrientos \& Kritzinger, 2004: 86; Du Toit \& Ally, 2003: 10-11). Off-farm, flexible workers are of course more vulnerable than permanent workers as regards their access to health care. Despite the increasing use of offfarm labour, most fruit producers still house the core of their permanent work force on the farm in order to retain the skills necessary to maintain production standards. The extension of employment as well as occupational health and safety regulation to agriculture during the nineties and the need to retain skills and productive workers have combined to potentially improve the employment conditions of these on-farm workers substantially.

\section{Methods}

Study design - An exploratory and descriptive study of all injuries occurring on selected farms, both occupational and other, needing some form of treatment, were documented for a one-year period to allow for seasonal variations in risk for injury type. Included variables looked at injuries in terms of gender, age, type of worker/non-worker, cause of injury, place and type of injury, body-part hurt, level of care required, severity of the injury, and alcohol relatedness. Exploratory and descriptive designs are used when very little information is available on a topic such as, in this case, injuries and causes of injuries in the agricultural sector. The goal is to provide basic background information or a context wherein more precise questions can be formulated for future more extensive and systematic research (Neuman, 1997: 19). The study proposal was reviewed and accepted by MRC and UCT experts in the field for methodological consistency and ethics. Population - The population from where the sample was chosen was fruit farms in the Western Cape. Farms with existing trained health workers were purposefully chosen from selected regions in the Western Cape. Documentation and analysis was done of all injuries on these farms involving all categories of workers and their families.

Sampling - A purposive non-probability sampling method was used. This method is suitable for exploratory studies where selection has a specific purpose, as is the case in the present study (Neuman, 1997: 204)

Forty eight fruit farms with a history of trained LHWs were purposefully selected from three areas in the Boland-Overberg region in the Western Cape. The background and training of the LHWs facilitated comprehension of the process of documentation of data and completion of questionnaires for the research project. A great advantage was that the lay health worker, as "fieldworker", was based on site and had ready access to information on injuries.

Instruments used - Injuries were documented by the LHW using a questionnaire to capture data on the injured as well as the circumstances of the injury episode. The questionnaire was a one-page, tick option instrument with one open question for written notes on reason for the injury.

Training - The LHWs received initial training in the use and correct completion of the questionnaire. The information on the forms was checked for validity and reliability and the process supervised on an ongoing basis by two supervisors appointed specifically for this purpose. Lay health workers had to hand in a monthly summary sheet of injuries for that period and this information acted as a further check for accuracy of the data. Regular feedback and training sessions where LHWs from an area met and exchanged information, proved to be very important in obtaining reliable information and fostering a good spirit and motivation for the project.

Analysis - Descriptive analysis using frequencies and percentages of key variables was done.

\section{Results}

A total of 500 injuries were recorded for the twelve-month period for the 48 selected farms. Keeping in mind that individual farms varied in size, in number of workers and families living on farms, and frequency of injuries per farm, an average of 10.4 injuries occurred per farm for the year, or 0.9 injuries per farm per month for the one-year period. Two deaths were recorded for this period.

The 500 injuries included injuries to all worker types (i.e. permanent, seasonal and contract) as well as to other nonworkers, including visitors that were hurt on the farm during the specified time. It was difficult to calculate a total number of workers on the farms or even total number of families on farms, because of the movement of people on and off farms. Permanent workers on farms were the most constant group with an average total of 2582 living on the 48 selected farms for the twelve-month period of the study.
On average $36 \%$ of these permanent workers were female. The average number of permanent workers on the farms ranged between 14 and 233. Contract and seasonal workers were employed on some of the farms for intermittent periods for fruit picking and packing depending on demand (more or less $10 \%$ respectively of the workers).

Because the unit of analysis was injuries, accurate rates per worker could not be calculated as some persons could have been injured more than once. The crude rate for occupational injuries for permanent workers, however, can be estimated at 8 injuries per 100 permanent workers per annum.

Half of the 500 injuries $(50.8 \%)$ that occurred on farms, were work-related. The rest of the injuries included injuries to children, visitors, pensioners, nonworking spouses and injuries to workers in their leisure time.

\section{Work-related Injuries}

More than two thirds of the work-related injuries were sustained by male workers. By far the more at risk were workers in the younger age group between 20 and 39 years of age (see Table I). Nearly $20 \%$ of these injuries were sustained by contract and seasonal workers $(9 \%$ and $10 \%$ respectively).

Most of the occupational injuries (60\%) were treated by the LHWs or nursing sisters on the farms (on some farms the farmers employ private nurses to visit the farm on a regular basis). The more serious injuries were treated by private practitioners or in private and state hospitals in the nearest town (Table l).

Workers were mostly injured while working in the orchards and with activities in and around the shed. These activities included, amongst others, activities such as fetching tools and materials needed for work; loading and unloading; handling of crates; welding and sawing activities. The type of injury sustained during working hours in most cases was cuts, bruises, abrasions and sprains (see Table II). Injuries such as backache and pain in one or more of the limbs or hands were indicated as "pain only'. In the majority of cases hands (including fingers) were hurt, followed by injuries to the eyes (including injuries to the head) and the leg and foot (Table II). A small percentage of injuries were caused by motor vehicles, including 


\begin{tabular}{|c|c|c|c|c|c|c|}
\hline & \multicolumn{2}{|c|}{ Occupational } & \multicolumn{4}{|c|}{ Non-occupational Total } \\
\hline & $\mathbf{n}$ & $\%$ & $\mathbf{N}$ & $\%$ & $\mathbf{N}$ & $\%$ \\
\hline \multicolumn{7}{|l|}{$\underline{\text { Sex }}$} \\
\hline Male & 173 & 68.1 & 177 & 71.6 & 339 & 70.0 \\
\hline Female & 81 & 31.9 & 69 & 28.4 & 147 & 30.0 \\
\hline Total & 254 & 100.0 & 246 & 100.0 & 500 & 100.0 \\
\hline \multicolumn{7}{|l|}{$\underline{\text { Age }}$} \\
\hline $0-9$ & - & - & 52 & 21.1 & 52 & 10.4 \\
\hline $10-19$ & 7 & 2.8 & 29 & 11.8 & 36 & 7.2 \\
\hline $20-29$ & 81 & 31.9 & 67 & 27.2 & 148 & 29.6 \\
\hline $30-39$ & 83 & 32.7 & 51 & 20.7 & 134 & 26.8 \\
\hline $40-49$ & 43 & 16.9 & 32 & 13.0 & 75 & 15.0 \\
\hline $50-59$ & 29 & 11.4 & 9 & 3.7 & 38 & 7.6 \\
\hline $60+$ & 11 & 4.3 & 6 & 2.4 & 17 & 3.4 \\
\hline Total & 254 & 100.0 & 246 & 100.0 & 500 & 100.0 \\
\hline \multicolumn{7}{|l|}{$\underline{\text { Person iniured }}$} \\
\hline Permanent worker & 204 & 80.3 & 154 & 62.6 & 358 & 71.6 \\
\hline Contract worker & 22 & 8.7 & 3 & 1.2 & 25 & 5.0 \\
\hline Seasonal worker & 26 & 10.2 & 12 & 4.9 & 38 & 7.6 \\
\hline Non worker (child, pensioner, visitor) & 2 & 0.8 & 77 & 31.3 & 79 & 15.8 \\
\hline Total & 254 & 100.0 & 246 & 100.0 & 500 & 100.0 \\
\hline \multicolumn{7}{|l|}{ Place of Iniury } \\
\hline Orchard & 165 & 65.0 & 16 & 6.5 & 181 & 36.2 \\
\hline Yard & 20 & 7.9 & 27 & 11.0 & 47 & 9.4 \\
\hline Home & 3 & 1.2 & 145 & 58.9 & 148 & 29.6 \\
\hline Road & 9 & 3.5 & 40 & 16.3 & 49 & 9.8 \\
\hline Shed & 46 & 18.1 & 10 & 4.1 & 56 & 11.2 \\
\hline Office & 6 & 2.4 & - & - & 6 & 1.2 \\
\hline Creche & 2 & 0.8 & 6 & 2.4 & 8 & 1.6 \\
\hline Community hall & - & - & 2 & 0.8 & 2 & 0.4 \\
\hline Unknown & 3 & 1.2 & - & - & 3 & 0.6 \\
\hline Total & 254 & 100.0 & 246 & 100.0 & 500 & 100.0 \\
\hline \multicolumn{7}{|l|}{ Level of care } \\
\hline LWH & 122 & 48.0 & 144 & 58.5 & 266 & 53.2 \\
\hline Clinic nurse & 31 & 12.2 & 6 & 2.4 & 37 & 7.4 \\
\hline Private doctor & 88 & 34.6 & 65 & 26.4 & 153 & 30.6 \\
\hline State hospital & 4 & 1.6 & 29 & 11.8 & 33 & 6.6 \\
\hline Priva:e hospital & 9 & 3.5 & 2 & 0.8 & 11 & 2.2 \\
\hline Total & 254 & 100.0 & 246 & 100.0 & 500 & 100.0 \\
\hline \multicolumn{7}{|l|}{ Day of injury } \\
\hline Monday & 34 & 13.4 & 25 & 10.2 & 59 & 11.8 \\
\hline Tuesday & 58 & 22.8 & 22 & 8.9 & 80 & 16.0 \\
\hline Wednesday & 48 & 18.9 & 23 & 9.3 & 71 & 14.2 \\
\hline Thursday & 55 & 21.7 & 30 & 12.2 & 85 & 17.0 \\
\hline Friday & 45 & 17.7 & 37 & 15.0 & 82 & 16.4 \\
\hline Saturday & 10 & 3.9 & 75 & 30.5 & 85 & 17.0 \\
\hline Sunday & 4 & 1.6 & 34 & 13.8 & 38 & 7.6 \\
\hline Total & 254 & 100.0 & 246 & 100.0 & 500 & 100.0 \\
\hline Alcohol relatedness of iniury & 11 & 4.3 & 115 & 46.7 & 126 & 25.2 \\
\hline Total & 254 & 100.0 & 246 & 100.0 & 500 & 100.0 \\
\hline
\end{tabular}




\section{Occupational}

n $\%$
Non-occupational Total

N $\%$

N $\%$

Cause of Iniury

Violence-related

Vehicle crash

Other accident*

Poison

Unknown

Total

\begin{tabular}{llllll}
- & - & 94 & 40.5 & 94 & 18.4 \\
14 & 5.5 & 9 & 3.9 & 23 & 4.6 \\
238 & 93.7 & 136 & 52.6 & 360 & 74.8 \\
2 & 0.8 & 5 & 2.2 & 7 & 1.4 \\
- & - & 2 & 0.9 & 2 & 0.4 \\
\hline 254 & 100.0 & 246 & 100.0 & 500 & 100.0 \\
\hline & & & & & \\
100 & 38.9 & 122 & 49.6 & 222 & 43.9 \\
36 & 14.0 & 42 & 17.1 & 78 & 15.4 \\
29 & 11.3 & 7 & 2.8 & 36 & 7.1 \\
23 & 8.9 & 10 & 4.1 & 33 & 6.5 \\
9 & 3.5 & 24 & 9.8 & 33 & 6.5 \\
22 & 8.6 & 9 & 3.7 & 31 & 6.1 \\
13 & 5.1 & 7 & 2.8 & 20 & 3.9 \\
6 & 2.3 & 10 & 4.1 & 16 & 3.2 \\
2 & 0.8 & 5 & 2.0 & 10 & 2.0 \\
17 & 6.6 & 10 & 4.1 & 27 & 5.3 \\
\hline 257 & 100.0 & 246 & 100.0 & 506 & 100.0 \\
\hline
\end{tabular}

Type of Injurv

Lacerations

Bruises

Abrasions

Sprains

Burns

Pain only

Fractures

Penetrating wounds

Poisonings

Other

Total

Bodv parts hurt

Head

Neck

Shoulder

Arm

Hand

Chest

Back

Abdomen

Hip

Leg

Foot

Multiple

Total

Davs off (Hospital and/or home)

0

$1-3$

46

$7+$

Total

\begin{tabular}{llllll}
64 & 24.7 & 79 & 31.9 & 143 & 28.2 \\
2 & 0.8 & 1 & 0.4 & 3 & 0.6 \\
6 & 2.3 & 13 & 5.2 & 19 & 3.7 \\
13 & 5.0 & 25 & 10.1 & 38 & 7.5 \\
101 & 39.0 & 52 & 21.0 & 153 & 30.2 \\
- & - & 10 & 4.0 & 10 & 2.0 \\
11 & 4.2 & 11 & 4.4 & 22 & 4.3 \\
1 & 0.4 & 6 & 2.4 & 7 & 1.4 \\
7 & 2.7 & 9 & 3.6 & 16 & 3.2 \\
26 & 10.0 & 14 & 5.6 & 40 & 7.9 \\
23 & 8.9 & 18 & 7.3 & 41 & 8.1 \\
5 & 1.9 & 10 & 4.0 & 15 & 3.0 \\
\hline $259 * *$ & 100.0 & 248 & 100.0 & 507 & 100.0 \\
\hline & & & & & \\
156 & 61.4 & 177 & 72.0 & 333 & 66.6 \\
77 & 30.3 & 43 & 17.5 & 120 & 24.0 \\
8 & 3.2 & 14 & 5.7 & 22 & 4.4 \\
13 & 5.2 & 12 & 4.8 & 25 & 5.0 \\
\hline 254 & 100.0 & 246 & 100.0 & 500 & 100.0 \\
\hline
\end{tabular}

*"Other accident" refers to the bulk of unintentional injuries caused by reasons other than vehicles, poison or violence.

**Total greater than 254 because more than one injury per person was documented. 
tractors. A few cases of work-related poisonings (two in total) were also documented. Both the poisoning cases involved the handling of pesticides.

Most of these injuries were not severe enough to take time off work. In $61 \%$ of the injury cases workers could go back to work after their injury was treated. A further $30 \%$ of the injured workers took one to three days off work. Only serious cases needed longer than a week to recuperate. No specific pattern could be detected related to the day of occurrence of the injury (Table II).

Four percent of the workplace injuries were reported to be alcohol related.

\section{Non work-related Injuries}

Almost half of the injuries documented were not work-related. More than $70 \%$ of these injuries affected males. A third of the non-work related injuries were sustained by children and youth under the age of 20 (21\% were injuries to young children under the age of ten). Nearly half of the non work-related injuries were sustained by people between the ages of 20 and 39 years (Table I). Most of the injuries occurred in and around the home. In the majority of cases the level of health care required was again mostly on the primary level and patients could therefore be treated by the LHW on the farm (Table I).

A total of $41 \%$ of the injuries that were not work-related were due to violence (Table II). This percentage went up to $62 \%$ for the age category of 20 to 39 years for violence. Most of these violent assaults were male on male incidents, but in $30 \%$ of the cases, women were the victims. The five cases of poisonings included two alcohol poisonings, one suicide case, one case of poisoning by pain pills involving a child and one case where a child had a rash due to the spraying of pesticides. The types of injury mostly sustained were cuts and bruises. Ten percent of these injuries were due to burns (Table II). Body parts hurt mostly included injuries to the head (including the scalp, eyes and face), and injuries to the hand (including fingers) and arm. Most of these injuries occurred over weekends (Table I).

In nearly half of all cases of injuries outside working hours, it was indicated that alcohol played a role. The percentage of alcohol-relatedness increased to $85 \%$ where injuries were due to violence.

\section{Discussion}

\section{Extent of the problem}

Keeping in mind the paucity of reliable data on agricultural injuries and difficulties associated with the comparison of data worldwide, the results of this study should be interpreted within its limits. The study was an exploratory and descriptive study, specific to deciduous fruit farming, set in the specific geographical area of the Western Cape, South Africa. The occupational injury rate per farm was higher than the similar rate for Australian farms ( 0.3 injuries per farm per annum in Australia, as against 5.0 injuries per farm per annum in this study) (Fragar, 1996: 200). A crude occupational injury rate for permanent workers, i.e. $8 /$ 100 workers per annum, compares with data quoted for international rates, i.e. 5 10/100 workers per annum (Dimich-Ward et al, 2004: 52). Variables to keep in mind when comparing injury rates are, for instance, source of information, type of farm production and injury severity.

\section{Nature and source of agricultural injuries}

Type of injury sustained in the workplace and the body part hurt was a reflection of the main production activities on fruit farms i.e. pruning, picking, transporting and packaging. Most of these injuries were not serious, but from an occupational health and safety point of view it is important to note that more than a third of the injured had to stay off work for one day or longer. The cost of absenteeism as well as the cost of health care to the farmer and to the health sector (nearly forty percent of the workers required care from a hospital or medical doctor) is substantial. Qualitative data on circumstances of injury indicated that many of the injuries were due to negligent behaviour. A meaningful number of injuries were due to workers not wearing protective clothing, eye protection or hand gloves when necessary. The safe use of tractors and ladders, for example, also need to be monitored. Education and training and the diligent implementation of safety regulations as indicated in the Occupational Health and Safety Act (Act no 85 of 1993), need to be institutionalised and adhered to. South Africa has a short history of legislation applying to the agricultural setting. Presently, managers of farms are obliged by law to be much more active in creating a safe work environment than pre-1994. Apart from legislative tightening of local safety specifications for the workplace, specifications from overseas markets and organisations pertaining to the quality of the exported product, the hygiene and safety of the workplace and social conditions of the workers on farms also place responsibility on farmers. EUROPGAP (Euro-retailer Fresh Produce Working Group's protocol on Good Agricultural Practices) and HACCP (Hazard Analysis and Critical Control Points - a system for good safety) are examples of such codes and specifications from outside the borders of South Africa.

\section{Non-work related injuries}

The present study confirms the welldocumented problems of alcohol abuse and related interpersonal violence as key public health issues on farms (London, Nell, Thompson et al, 1998: 1096; Sunde \& Kleinbooi, 1999: 58; Parenzee \& Smythe, 2003: 3). Alcohol abuse and its role in violent incidents, but especially in cases of domestic violence, is seen as a common occurrence on many of the farms in the Western Cape (Sunde \& Kleinbooi, 1999: 51; Parenzee \& Smythe, 2003: 30). In fact, the seriousness of domestic violence is often dismissed by attributing violence to the abuse of alcohol, thereby suggesting that violence is merely the anticipated outcome of excessive alcohol abuse, often by both partners (Sunde \& Kleinbooi, 1999: 58).

Farm workers have inherited a considerable burden of morbidity as a result of the historical legacy of poor living and working conditions in the agricultural sector (London, Nell, Thompson et al, 1998: 1096). Initiatives such as the DOPSTOP-Association (a non-profit organisation dedicated to address alcohol abuse on farms), the Women on Farms Project, and ongoing interventions to address the high incidence of foetal alcohol syndrome in selected communities in the Western Cape, are examples of attempts to address the scourge of alcohol abuse, poverty and related social problems.

\section{Involvement of lay health workers}

Community based health workers include a variety of health auxiliaries who are selected and trained and work in the communities in which they live. They perform a wide range of functions and 
have been incorporated in programmes dealing with tuberculosis control, HIV/ Aids counseling and other interventions regarding general issues related to health care delivery and welfare (Friedman, 2002: 162; Clarke, 2005: 3). The value and cost effectiveness of these workers have been documented for a range of tasks (Friedman, 2002: 179). Historically the concept can be associated with the World Health Organisation's Alma Ata Declaration of 1978 to establish the primary health care paradigm through the participation of communities. In the present study, the LHWs acted as an important primary source of care to injured patients. Widespread agreement exists that community based health workers (if trained properly) in whatever form have a role to play in improving the health of communities and to fill the gap in especially under-resourced rural areas where the existing formal health care services cannot reach (Friedman, 2002: 180). Most importantly, the LHWs participating in the study proved that an important additional function could be to document basic information on injuries (amongst others) on farms which can make an important contribution to the systematic, ongoing surveillance of injuries on farms in South Africa.

\section{Conclusions and implications}

An agricultural injury surveillance system to identify the extent and nature of injuries on farms is a necessary first step towards prevention. Recent occupational health and safety legislation in South Africa still needs to be institutionalized and adhered to. Alcohol abuse and accompanied violence on farms is a serious public health problem. LHWs on farms could potentially play an important role in documenting injury data as well as act as primary care provider.

\section{Acknowledgement}

The authors wish to express their thanks to Hilton Donson for assistance with data analysis.

\section{References}

BARRIENTOS, S \& KRITZINGER, A 2004: Squaring the circle: Global production and the information of work in South African fruit exports. Journal of International Development. (16):81-92.
BAXTER, P 1992: Health and safety on the farm. British Medical Journal. 305(6844): 6-7.

CLARKE, M 2005: Towards costeffective tuberculosis control in the Western Cape of South Africa: intervention study involving lay health workers on agricultural farms. Stockholm: Karolinska University Press.

DEMERS,P \& ROSENSTOCK, L 1991: Occupational Injuries and Illnesses among Washington State Agricultural Workers. American Journal of Public Health, 81(12):1656-1658.

DIMICH-WARI), H; GUERNSEY, JR; PICKETT, W; RENNIE, D; HARTLING, L; BRISON,RJ 2004: Gender differences in the occurrence of farm related injuries. Occupational and Environmental Medicine. (61): 52-56.

DU TOIT, A \& ALLY, F Dec. 2003: The externalization and causalisation of farm labour in Western Cape horticulture: A survey of patterns in the agricultural labour market in key Western Cape districts and their implications for employment justice. Research Report no. 16. Program for land and agrarian studies and Centre for rural legal studies. School of Government, University of the Western Cape, South Africa.

FRAGAR, L 1996: Agricultural Health and Safety in Australia. Australian Journal of Rural Health. (4):200-206.

FRIEDMAN, I 2002: Community Based Health Workers. South African Health Review. Durban: Health Systems Trust, South Africa, 161-180.

GUNDERSON, P; GERBERICH, S; GIBSON, R; ADLIS, S; CARR, P; ERDMAN, A 1990: Injury surveillance in agriculture. American Journal of Industrial Medicine. (18):169-178.

HARTLING, l; PICKETT, W; BRISON, R 1998: The Canadian Agricultural Injury Surveillance Program: A New Injury Control Initiative. Chronic Diseases in Canada. 19(3): 108-111.

HAYDEN, G; GERBERICH, S; MALDONADO, G 1995: Fatal farm injuries: A five year study utilizing a unique surveillance approach to investigate the concordance of reporting between two data sources. Journal of Environmental Medicine. 37(5):571-577.
JEEBHAY, M; JACOBS, B 1999: Occupational health services in South Africa, In: Crisp. N \& Ntuli, A Eds. 1999: South African Health Review. Durban: Health System's Trust (19):257-276.

KELLEY, H 1994: Farm-related injury fatalities in Oklahoma, 1987-1991. Journal of Oklahoma State Medical Association. 87(3):112-114.

LONDON, L; NELL, V; THOMPSON, M-L; MYERS, JE 1998: Health status among farm workers in the Western Cape - collateral evidence from a study of occupational hazards. South African Medical Journal. 88 (9): 1096- 1101.

MMWR (Morbidity and Mortality Weekly Report). April 2001: Fatal occupational injuries - United States, 1980-1997. 50(16):317-320.

MYERS, J 1990: National Surveillance of Occupational Fatalities in Agriculture. American Journal of Industrial Medicine. (18):163-168.

NEUMAN, WL 1997: Social research methods - Qualitative and quantitative Approaches. London: Allyn \& Bacon.

PARENZEE, P \& SMYTHE, D 2003: Domestic violence and development: Looking at the farming context. Cape Town: Institute of Criminology, University of Cape Town.

REPUBLIC OF SOUTH AFRICA 1994: The Occupational Health and Safety Act, Act no 85 of 1993. Pretoria: Government Printer.

ROGERS,F; SHACKFORD,S; OSLER, T; VANE, D; DAVIS, J 1997: Rural Trauma: The challenge for the next decade. The Journal of Trauma: Injury. Infection and Critical Care 47 (4): 802 821.

SUNDE, J \& KLEINBOOI, K 1999: Promoting equitable and sustainable development for women farm workers in the Western Cape. Stellenbosch: Centre for Rural Legal Studies. 